\author{
Małgorzata JANUS-MICHALSKA ${ }^{1}$ \\ Dorota JASIŃSKA ${ }^{2}$
}

\title{
COMPARATIVE STUDY OF BENDING STIFFNESS OF SANDWICH PLATES WITH CELLULAR CORES
}

\begin{abstract}
This paper presents numerical simulation of a sandwich plate bending. Two types of plates are considered: with a cellular honeycomb core and with the cellular auxetic core. Finite element method (FEM) calculations are performed by means of ABAQUS system for determination of plates bending stiffness. Three methods are presented. The first one, numerically expensive, is based on detailed modelling of cellular core structure, the second applies laminated plate theory with an equivalent core stiffness, the third applies theory of composite beams. The results show limitations of applicability of abovementioned models to stiffness modelling. The influence of core lattice geometry parameters on plate stiffness is studied.
\end{abstract}

Keywords: sandwich plates, auxetic cellular material, cellular core

\section{Introduction}

Sandwich plates are used in many engineering applications due to improved bending stiffness and lightness. Such structures efectively resist bending and buckling load. Sandwich panel consists of two face sheets made of high density usually isotropic material, and low density core. Core material should have high shear rigidity to prevent sliding of face panels. Cellular materials are widely used for a core structure. Sandwich panels rigidity can be tailored for specific designer demands by the choice of core structural parameters. First studies on the subject were performed by Gibson and Ashby, Warren and Kraynik, Torquato, for regular hexagonal or tubular cellular core microstructures.

Assesment of elastic properties of sandwich panels with cellular core are given in works by Burton and Noor [2] or Hohe and Becker [4]. Triangular grid structures were studied by Hohe Becker [5-7]. Little attention has been paid to cores with material symmetries other than isotropic or orthotropic. The effective properties of honeycomb core material have been the subject of previous works

\footnotetext{
1 Autor do korespondencji/corresponding author: Małgorzata Janus-Michalska, Politechnika Krakowska, Warszawska 24, tel. 12 6282346, e-mail: mjanus-michalska@pk.edu.pl

2 Dorota Jasińska,_Politechnika Krakowska, e-mail: djasinska@pk.edu.pl
} 
by many authors, for example Burton [2] and Shi and Pin [13]. The determination of stiffness matix for core equivalent medium is based on homogenization procedures. Continuum model is described in works by Burton [2], energetic homogenization by Hohe [6]. Bending gradient plate theory is applied to thick sandwitch plates by Lebee and Sab $[10,11]$. Cellular core material can possess auxetic properties due to special arrangement of cells geometry. Auxetics reveal special mechanical properties. For cores with small amount of cells mechanical properties can be evaluated by considering size effect.

The work presented here is focused on comparison of typical honeycomb core with auxetic core due to its expected specific properties such as negative Poisson's ratio and increased shear stiffness as described by Alderson [1] Greaves [3]. In this paper the evaluations of sandwich plate stiffness for cellular material with honeycomb and auxetic inverted honeycomb structures is carried out by three different methods and compared.

\section{Methods of evaluation of bending stiffness rigidity}

The first method, numerically expensive, is based on detailed modelling of both cellular core and two facings structure. The shell model for facings and solid for core is adopted. The whole structure is discretized by finite elements. Numerical calculations by means of finite element method (FEM) are performed in ABAQUS system.

The second method is analytical and applies the theory of a laminate with equivalent core stiffness. The idea of applying the laminate plate theory is not new. It was applied by Meraghni et al. [12]. Although the laminate theory is valid for thin layers it can be used for determining equivalent rigidities. The sandwich panel adopted to the theory of laminated plate is illustrated in figure 1 .

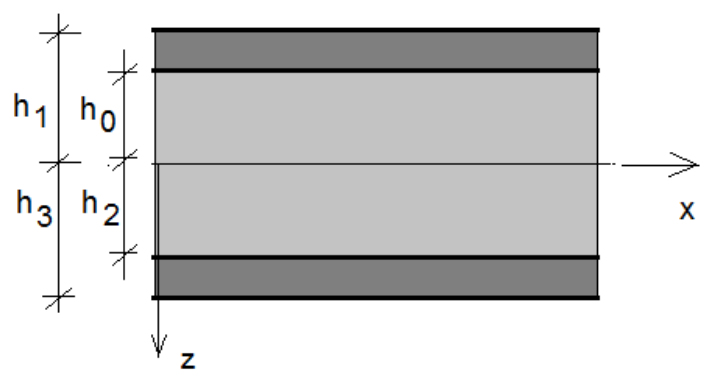

Fig. 1. Sandwich panel as a laminate structure

Generalized stress-strain relations for a laminate are written as follows [5]:

$$
\left(\begin{array}{l}
\mathbf{N} \\
\mathbf{M}
\end{array}\right)=\left(\begin{array}{ll}
\mathbf{A} & \mathbf{B} \\
\mathbf{B} & \mathbf{D}
\end{array}\right)\left(\begin{array}{l}
\boldsymbol{\varepsilon} \\
\mathbf{k}
\end{array}\right)
$$


where: $\mathbf{N}, \mathbf{M}$ mean longitudinal force and bending moment, whereas $\varepsilon$ and $\mathbf{k}$ are elongation and curvature respectively.

For sandwich with symmetrical layers submatrix $\mathbf{B}$ equals zero. Bending relation can be written as follows:

$$
\mathbf{M}=\mathbf{D} \mathbf{k}
$$

D matrix components are given by the formula [5]:

$$
\mathrm{D}_{\mathrm{ij}}=3 \sum_{\mathrm{n}}\left[\mathrm{Q}_{\mathrm{ij}}^{\mathrm{n}}\left(\mathrm{h}_{\mathrm{n}}^{3}-\mathrm{h}_{\mathrm{n}-1}^{3}\right)\right]
$$

where: $\mathrm{Q}_{\mathrm{ij}}^{\mathrm{n}}$ - stiffness matrix for layer number $\mathrm{n} ; \mathrm{h}_{\mathrm{n}}$ - distance from $\mathrm{x}$-axis to exterior of layer number $n$

For bending in xz plane the resultant moment equals:

$$
M_{y}=\int_{-h / 2}^{h / 2} \sigma_{x} z d z
$$

Transverse shear Q is not incorporated into the theory. Plane stiffness matrix for core material is represented as follows:

$$
\boldsymbol{\sigma}=\mathbf{Q} \boldsymbol{\varepsilon} \rightarrow\left(\begin{array}{c}
\sigma_{\mathrm{x}} \\
\sigma_{\mathrm{z}} \\
\tau_{\mathrm{xz}}
\end{array}\right)=\left(\begin{array}{lll}
\mathrm{Q}_{11} & \mathrm{Q}_{12} & \mathrm{Q}_{13} \\
\mathrm{Q}_{12} & \mathrm{Q}_{22} & \mathrm{Q}_{23} \\
\mathrm{Q}_{13} & \mathrm{Q}_{23} & \mathrm{Q}_{33}
\end{array}\right)\left(\begin{array}{c}
\varepsilon_{\mathrm{x}} \\
\varepsilon_{\mathrm{z}} \\
\gamma_{\mathrm{xz}}
\end{array}\right)
$$

Stiffness matrix of equivalent continnum for core material can be obtained by the use of micromechanical model of cellular materials (Janus-Michalska [8]). Effective material constants such as Young modulus and Poisson's ratio are derived on the basis of stiffness matrix.

The third method applies the theory of composite beams ([9] Kollar). The core Young modulus is denoted $\mathrm{E}_{0}$. The weight of facings material is given as below:

$$
\mathrm{n}_{1}=\frac{\mathrm{E}_{1}}{\mathrm{E}_{0}}
$$

The bending stiffness of the beam is defined as follows:

$$
\mathrm{D}=\mathrm{E}_{\mathrm{o}} \mathrm{J}
$$

where the weigted moment of inertia $\mathbf{J}$ with respect to bending axis is defined as below:

$$
\mathrm{J}=\sum_{\mathrm{i}=0}^{1} \mathrm{n}_{\mathrm{i}} \mathrm{J}_{\mathrm{i}}
$$




\section{Core cellular structure}

Two types of cellular structures are taken into account: inverted honeycomb and honeycomb as shown in figure 2. The microstructures can be described by representative volume elements with geometric parameters $\mathrm{L}, \mathrm{H}, \gamma$. Two microstructural orientations with respect to global system of coordinates are considered: horizontal and vertical as shown in figure 3.
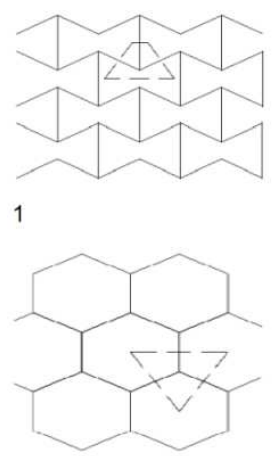

Fig. 2. Auxetic and honeycomb cellular structure with representative volume element

$1 \mathbf{a}$
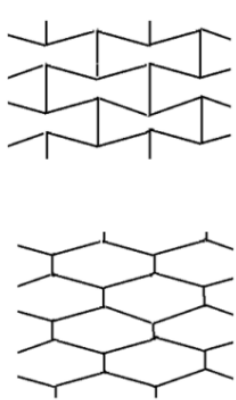

2a

Fig. 3. Orientations of cellular microstructures: a) horizontal, b) vertical

As a structural example sandwich plates with four types of core are considered. The adopted material of cellular skeleton is elastomer Fibro with the following material data: $\mathrm{E}_{\mathrm{s}}=38 \mathrm{MPa}, v=0.3,{ }^{\mathrm{s}} \mathrm{R}_{\mathrm{m}}=36 \mathrm{MPa}$.

Cellular core structures with geometric parameters given in Table 1 are considered. In order to give material elastic constants and stiffness matrices of equivalent media computer calculations were carried out in the environment of 
Abaqus program. The detailed method of core homogenization is described by Janus-Michalska [8]. Equivalent material constants for the core material are collected in Table 2.

Table 1. Microstructural geometric parameters

\begin{tabular}{|c|l|l|l|c|}
\hline Structure & $\mathrm{L}[\mathrm{mm}]$ & $\mathrm{H}[\mathrm{mm}]$ & $\mathrm{t}[\mathrm{mm}]$ & $\gamma\left[^{\circ}\right]$ \\
\hline 1 & 9.0 & 8.7 & 1.0 & 80 \\
\hline 2 & 9.0 & 8.7 & 1.0 & 100 \\
\hline
\end{tabular}

Table 2. Equivalent core material constants

\begin{tabular}{|c|c|c|c|c|}
\hline Structure & Ex [MPa] & nixz & Ez [MPa] & nizx \\
\hline 1a & 1.5 & -4.86 & 0.042 & -0.145 \\
\hline 1b & 0.045 & -0.145 & 1,5 & -4.86 \\
\hline 2a & 1.5 & 4.9 & 0.04 & 0.14 \\
\hline 2b & 0.045 & 0.145 & 1.5 & 4.86 \\
\hline
\end{tabular}

Stiffness matrices for auxetic core structures in horizontal and vertical orientations (structures $1 \mathrm{a}$ and $1 \mathrm{~b}$ in fig. 3 ) are given below:

$$
\mathbf{Q}=\left(\begin{array}{ccc}
4.740 & -0.833 & 0 \\
-0.833 & 0.134 & 0 \\
0 & 0 & 0.0154
\end{array}\right) \quad \mathbf{Q}=\left(\begin{array}{ccc}
0.134 & -0.833 & 0 \\
-0.833 & 4.740 & 0 \\
0 & 0 & 0.0154
\end{array}\right)
$$

For honeycomb core with horizontal and vertical orientation (structures $2 \mathrm{a}$ and $2 \mathrm{~b}$ in fig.4 respectively ) stiffness matrices are as follows:

$$
\mathbf{Q}=\left(\begin{array}{ccc}
5.024 & 0.679 & 0 \\
0.679 & 0.131 & 0 \\
0 & 0 & 0.0460
\end{array}\right) \quad \mathbf{Q}=\left(\begin{array}{ccc}
0.131 & 0.679 & 0 \\
0.679 & 5.024 & 0 \\
0 & 0 & 0.0460
\end{array}\right)
$$

Facesheets are assigned isotropic elastic properties of elastomer fibro with the resulting stiffness matrix:

$$
\mathbf{Q}=\left(\begin{array}{ccc}
41.76 & 12.53 & 0 \\
12.53 & 41.76 & 0 \\
0 & 0 & 29.23
\end{array}\right)
$$

The tested plate dimensions shown in figure $4: 2 \mathrm{~h}_{0}=44.3 \mathrm{~mm}, \mathrm{~d}=3.0 \mathrm{~mm}$, $\mathrm{L}=1.0 \mathrm{~m}$. We consider a long rectangular sandwich plate, whose length is large compared with its width. The long edges are simply supported. The beam model of unit width $\mathrm{g}=1.0$ is adopted. The model is supported and loaded in a manner presented in figure 4 . The plate is subjected to a uniform load $q=1 \mathrm{kN} / \mathrm{m}$. Four types of considered cores are illustrated in figure 5. 


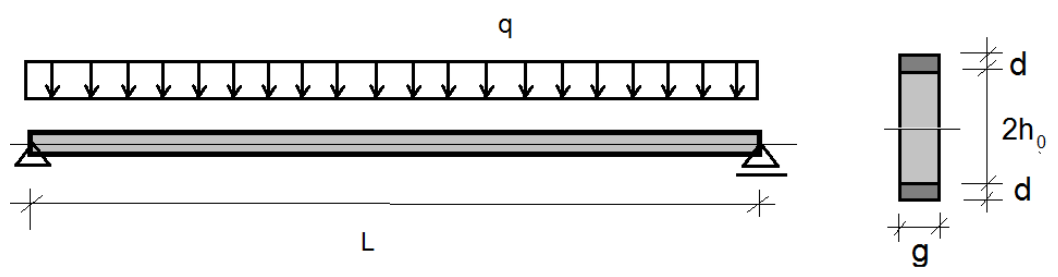

Fig. 4. Beam cross section dimensions and static scheme

$1 \mathbf{a}$

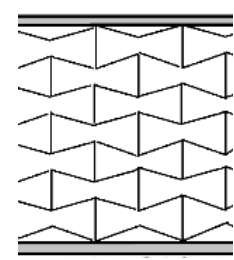

$\mathbf{2 a}$

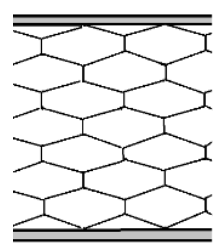

$1 \mathbf{b}$

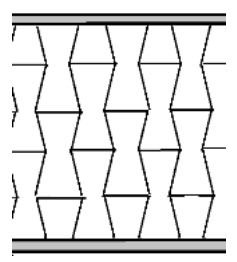

$2 \mathbf{b}$

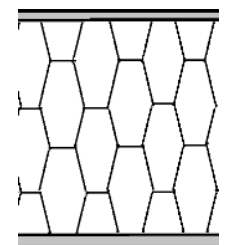

Fig. 5. Types of cores: $1 \mathrm{a}$ - horizontal inverted honeycomb, $1 \mathrm{~b}-$ vertical inverted honeycomb, $2 \mathrm{a}$ - horizontal honeycomb, $2 \mathrm{~b}$ - vertical honeycomb.

\section{Beam deflection}

The analytical solution for deflection of a point in the beam midspan is well known and given by the formula:

$$
\mathrm{w}\left(\frac{1}{2}\right)=\frac{5 \mathrm{ql}^{4}}{384 \mathrm{D}}
$$

For sandwich plates the deflection is as given below (Kollar [9]):

$$
\mathrm{w}\left(\frac{1}{2}\right)=\frac{5 \mathrm{ql}^{4}}{384 \mathrm{D}}+\frac{\mathrm{ql}^{2}}{8 \mathrm{~S}}
$$

where: $\mathrm{S}=\frac{\left(\mathrm{h}_{0}+\mathrm{h}_{1}\right)^{2}}{2 \mathrm{~h}_{0}} \mathrm{Q}_{33}$

In order to solve numericaly discussed sandwich panels with different cellular cores, FEM models, described in point 2.1, are prepared. Both core 
structures and facesheets are discretized by planar Timoshenko beam elements: cores by ca. 5700 elements, and facesheets by ca. 1000 elements. The finite element analysis is performed by means of ABAQUS system. Numerically obtained deflections are compared with analytical solutions for laminate and composite beam theories. The results are collected in table 3 .

Table 3. Comparison of beam deflections

\begin{tabular}{|c|c|c|c|}
\hline structure & $\begin{array}{c}\mathrm{w}[\mathrm{mm}] \\
\text { ABAQUS }\end{array}$ & $\begin{array}{c}\mathrm{w}[\mathrm{mm}] \\
\text { laminate } \\
\text { theory }\end{array}$ & $\begin{array}{c}\mathrm{w}[\mathrm{mm}] \\
\text { composite } \\
\text { beam }\end{array}$ \\
\hline 1a & 22.78 & 20.362 & 40.11 \\
\hline $2 \mathrm{a}$ & 21.40 & 20.603 & 40.11 \\
\hline 1b & 11.76 & 16.472 & 34.06 \\
\hline $2 \mathrm{~b}$ & 11.98 & 16.469 & 34.06 \\
\hline
\end{tabular}

\section{Conclusions}

The theory of laminates can be acceptable to model the presented plate with cellular core. The theory of composite beams seems to be inadequate for modeling such beams. Geometric parameters of a core structure have an impact on equivalent core material properties, which allows to tailor material for specified utility conditions. Auxeticity has not meaningful influence on results compared with cores of positive Poisson's ratio. The magnitude of Poisson's ratio increases the bending stiffness of considered beam. Shear rigidity does not give meaningfull correction to calculated deflections by the theory of laminates for the considered structure.

Since cores presented in above examples are built with small amount of cells per height, hence equivalent properties can be estimated not properly due to size effect. We expect to improve the results presented in Table 3 by introducing the study on the size effect for equivalent continuum of core.

\section{References}

[1] Alderson A., Alderson K.L.: Auxetic materials, Proc.Institution of Mechanical Engineers, Part G, J. Aerospace Eng., Special Issue Paper 2007, pp. 565-575.

[2] Burton W.S., Noor A.K.: Assesment of continuum models for sandwich panel honeycomb cores, Comput. Methods Appl. Mech. Eng., 145 (1999) 341-360.

[3] Greaves G.N., Greer A.L., Lakes R.S., Rouxel T.: Poisson's ratio and modern materials, Modern Materials, 24 October 2011, DOI: 10.1038 NMAT 3134.

[4] Hohe J., Becker W.: A mechanical model for two-dimensional cellular sandwich cores with general geometry in sandwich construction, Comput. Materials Sci., 19 (2000) 108-115.

[5] Hohe J., Becker W.: A refined analysis of the effective elasticity tensor for general cellular sandwich cores, Int. J. Solids Structure, 38 (2001) 3689-3717. 
[6] Hohe J., Becker W.: An energetic homogenization procedure for the elastic properties of general cellular sandwich cores, Composites Part B, 32 (2001) 299-312.

[7] Hohe J.: A direct homogenization approach for determination of the stiffness matrix for microheterogeneous plates with application to sandwich panels. Composites Part B, 34 (2003) 615-626.

[8] Janus-Michalska M.: Micromechanical model of auxetic cellular materials, J. Theor. Applied Mech., 47 (2009) 5-22.

[9] Kollar L.P., Springer G.S.: Mechanics of Composite Structures, Cambridge University Press, 2003.

[10] Lebee A., Sab K.: Transverse shear stiffness of a chevron folded core used in sandwich construction, Int. J. Solids Structures, 47 (2010) 2620-2629.

[11] Lebee A., Sab K.: Homogenization of thick plates: Application of the bending gradient plate theory to a folded core sandwich panel, Int. J. Solids Structures, 49 (2012) 2778-2792.

[12] Meraghni F., Desrumaux F., Benzeggagh M.L., Mechanical behaviour of cellular core for structural sandwich panels, Composites: Part A, 30 (1999) 767-779.

[13] Shi G., Pin T., T., Equivalent Transverse Shear Stiffness of Honeycomb Cores, Int. J. Solids Structures, 32 (1995) 1383-1392.

\section{STUDIUM PORÓWNAWCZE SZTYWNOŚCI GIĘTNEJ PLYTY SANDWICHOWEJ Z WYPEŁNIENIEM MATERIAŁEM KOMÓRKO- WYM O STRUKTURZE HONEYCOMB ORAZ Z WYPEENIENIEM AUKSETYCZNYM}

\section{Streszczenie}

W artykule przedstawiono numeryczne symulacje testów zginania płyt sandwichowych wypełnionych materiałami komórkowymi o strukturze plastra miodu oraz strukturze auksetycznej. Celem wyznaczenia sztywności giętnej płyt wykonano obliczenia numeryczne w systemie ABAQUS metodą elementów skończonych. Prezentowane są dwie metody. Pierwsza kosztowna numerycznie polega na szczegółowym modelowaniu struktury komórkowej, druga stosuje teorię laminatów, trzecia teorię belek zespolonych. Wyniki wskazują na możliwość modelowania sztywności giętnej płyty. Przeanalizowano wpływ parametrów geometrycznych, a w szczególności auksetyczności struktury.

Słowa kluczowe: płyty sandwichowe, auksetyczne materiały komórkowe

DOI: $10.7862 / \mathrm{rm} .2017 .17$

Przestano do redakcji: 12.01.2017

Przyjęto do druku: 2.04.2017 